\title{
Farming Practices and Knowledge in Vegetable-Growing Farms: An Economic Survey in Three Years Farming
}

\author{
EDWIN M. PUHAGAN, PH.D. \\ Office of the Production, TRAC \\ NURSHIMA H. JULJANI, ELENA E. KUHUTAN, ALSADAM E. PUHAGAN, RASHID HALIPA \\ Office of the Production, Agriculture Department, Tawi-Tawi Regional Agricultural College
}

\begin{abstract}
This study conducted based on the issues of local agriculture economic capabilities of the small farmers distributed among municipalities of Tawi-Tawi with its aim of providing feedback with regard to socioeconomic of local vegetable farmers during farm operation periods in 2016 up to 2019. It collected several indicators of socioeconomic that are deem products of vegetable farming framework and focused on the following specific problems: What is the socioeconomic profile among local vegetable farmers in terms of the following indicators such as, age, civil status, family members, household, type of house, ownership, farm size, food security, gender participation in farming and annual net income? Is there variation of socioeconomic status among vegetable farmers in three years farming? What are vegetable farming practices and knowledge learned from the services offered by the agricultural institutions adapted in three years vegetable-growing farms? What is the level expenditure by farmers in three years vegetable farming? Is there significant influence of vegetable farming practice as profession on the socioeconomic of the local famers? Only graduates of agriculture who farmers themselves were invited as respondents. The design used was descriptive. Its respondents comprised individuals who learned knowledge of farming offered by the Tawi-Tawi Regional Agricultural College in three academic years 2016-2019. The data interpreted using percentages and frequencies; mean and standard deviation through Likert scaling of the responses. For more concrete, it used all tools packaged in the SPSS software. This study is phenomenal in nature across the impact of farming on the socioeconomic of the vegetable farmers and its interpretation explicitly coupled with the literatures relevant to the issue on Tawi-Tawian VegetableGrowing Farms: An economic survey in three years farming. Respondents were in 35-40 age bracket, married, having 8-10 members in family living in one roof with 2-extended families attached, living in wooden nipa house with personally own garden lot and with food sustained by their respective harvest, almost all male participates in farming and gaining an annual net income of $130 \mathrm{k}$ to $160 \mathrm{k}$.
\end{abstract}

The Tawi-Tawian vegetable-growing farms had exclusively outdoor vegetable farming operation in the same system with slight variation in three years. Variables such as gender participation in farming, age, civil status, household size, food security and environment, income, family members and farm size are determinants to the socioeconomic of local farmers and the relationship among identified variables leads to conclusions about the influence of farming in reducing poverty hence, farming improves socioeconomic of those who engaged on it as a vocation. The strength of vegetable production pertaining to the area planted with vegetables affecting the socioeconomic depends upon the knowledge learned and practices adapted by farmers in farming. The increasing percentage of expenditure on vegetables farming related works over time per farm implies slight variation of total area planted to vegetables on individual farms from year to year. The farmers' expenditures across all years, on average, the ratio of expenditures over the area planted each year varied by only very less percentage and very slight variation ranged in the value of peso and the percentage of expenditure. Further, the was a significant influence of vegetable farming practices as profession on the socioeconomic among vegetable farmers in Tawi-Tawi province.

Keywords:- Tawi-Tawi, vegetable growing farms, expenditures, socioeconomic farm practices, knowledge learned

\section{INTRODUCTION}

The Tawi-Tawian vegetable growing sector is an important source of food in the province. It supplies most of the fresh vegetables consumed in Tawi-Tawi and provide inputs for the preservation of the same distributed to 11 municipalities. Exportation is not an issue to this effect where around 80 percent of the vegetable locally produced by all growers for home consumption in 2017-18, 2018 to 19 and 2019-20. Vegetable growing perhaps given the least priority by the locales as profession in Tawi-Tawi, however, the level of dependency in agriculture for food across the province is seen foremost prevalent following the increase of its increasing population. The main land Tawi-Tawi is hilly and heavily wooded serving as comfort zone for the wildlife species, with splashes of white sandy 
beaches and rock-bound coast for marine life. Most of the people in Tawi-Tawi belong to Sama cultural group, Jama Mapun, Bajao and the Tausog. Tawi-Tawi claims its unique historical identity of being the earliest home of Islam in the Philippines in 1380 where Sheik Karim ul-Makhdum established the first mosque in Simunul and continuedly reserved by Muslims in the Philippines. In early $14^{\text {th }}$ century, Tawi-Tawi had become part of the kingdom of Sulu Sultanate and remain free from Spanish and western intervention as a result of Philippine revolution. Since then, farming as a vocation of the local villagers became more apparent and continually producing agriculture products in addressing normal diet needs which they eventually adapted new technologies in agricultural production system for economic enhancement, benefits and daily life sustainability. Tawi-Tawi has only one higher institution catering agricultural curriculum, where over the past several years or so, huge number of students graduated from agricultural curriculum who carried corresponding researches conducted and read before completion of their academic requirements, reporting along issues of agricultural productivity, the effects of agricultural research and development, the technology of agricultural innovation and productivity patterns, and the resulting remunerations gained from investments in farming. Now, it is a high time to evaluate and reveal contribution of learned curriculum on the socioeconomic status of graduates who deemed to be great contributors to economy as farmers themselves. This article summarizes and interprets the socioeconomic findings with emphasis on the implications of the different farming methods learned and used by the farmers.

The socioeconomic in farming could be attributed to a wide range of situations depending upon the level of development of the respective places with different scenarios. In Tawi-Tawi, farming is a profession sustaining socioeconomic status where many depends on and refer this profession as an umbrella resulted from the varied interactions among people, plants and animals with series of related activities mainly for production of different agricultural products for home consumption, marketing and economic purposes. Straightforwardly, the Tawi-Tawi Regional Agricultural College is established and developed its curriculum catering information dissemination in addressing human needs mainly food requirements of people in the province. The college envisions its objective of providing agricultural-technical education for anyone who in the future are expected to be knowledgeable in farming, conservation of the landscape, land preservation and other activities without compromising the environment and its agricultural resources but a great contributor to the economy. Since the earliest stage of agricultural curriculum program of the college, farming has been well-thought-out as an economic activity graduates distributed in the eleven municipalities of the province. However, as this is the most widespread form of human activity, it also has important implications for other uses of land and the conservation of agricultural resources towards socioeconomic standing of farmers.

\section{A. Significance of the study:}

In principle, this study conducted based on the issues of local agriculture economic capabilities of the small farmers distributed among municipalities of Tawi-Tawi. It aims at providing feedback to the agriculture sector in Tawi-Tawi with regard to socioeconomic status of the local vegetable farmers and business opportunities and strengthening the role of agriculture sector played with regard to economic enhancement. It summarizes the key findings resulting from a literature search, a collection of data on economic input during farm operation periods in three years farming starting 2016 up to 2019.

Farming is dominant occupation among villagers residing in the remote areas of the province with high percentage of the land surface utilized for agricultural production in some form. A noteworthy part of TawiTawi's natural heritage including its biodiversity can be found within rural landscapes. There are mutual and complex interactions between agriculture and socioeconomic of the farmers known as the economic needs farming and it influences farming. The farming as a vocation is one of the most important professions that can provide economic benefits through the application of sustainable management systems and the adoption of alternative and innovative technologies and practices.

Farming activity is one of the major drivers of economic stability yet Tawi-Tawi is still mobilizing agriculture in extreme proportions of its own environment, climate, and invasive species over its teeming population. Information resulted from this study is very significant to the farmers and the agriculture service providers like the Tawi-Tawi Regional Agricultural College and other agricultural development line agencies. This is further enhanced by understanding interactions among variables of the socioeconomic and translating them into farming management practices to ensure safe and sufficient delivery of farming products and services where Tawi-Tawians and the people from neighboring places benefit from it. Socioeconomic opportunities in farming industry are supported by an increasingly robust collection of farming technologies that enable farm-sectors adopt farmingresponsible practices and develop their resources-base goods and services.

\section{B. Research problems}

Given from the issue mentioned above, this study collected several indicators of socioeconomic that are deem products of vegetable farming framework and evaluates the effective application of best practices and knowledge learned from the services offered by the learning institution adapted at the farm and landscape levels that may have created synergies among components of farming and the provision of socioeconomic services to the farmers. It is a significant study on how to change behavior of farmers to pursue farming-friendly practices in the future. The possibilities of exchanging experiences and networking among the relevant stakeholders, investors and farmers essential to the practical application across farming geographical boundaries in the whole province. This 
focused on the following specific problems enumerated below such as:

$>$ What is the socioeconomic profile among local vegetable farmers in terms of the following indicators such as, age, civil status, family members, household, type of house, ownership, farm size, food security, gender participation in farming and annual net income?

$>$ Is there variation of socioeconomic status among vegetable farmers in three years farming?

$>$ What are vegetable farming practices and knowledge learned from the services offered by the agricultural institutions adapted in three years vegetable-growing farms?

What is the level expenditure by farmers in three years vegetable farming?

Is there significant influence of vegetable farming practice as profession on the socioeconomic of the local famers?

\section{Hypothesis}

The authors have assumed the following null hypothesis all throughout the conduct of this study such as:

$>$ Hypothesis number 1. There is no variation of socioeconomic profile among farmers in three years farming.

$>$ Hypothesis number 2. There is no significant influence of vegetable farming practice as profession on the socioeconomic of the local famers.

\section{Scope and Delimitation}

It is very significant to note the socioeconomic status of farmers in several years, however, this study only investigated three most recent successive years of farming activities among villagers who deem producers of vegetables. This was delimited to indicators such as, age, civil status, family members, household, type of house, ownership, farm size, food security, gender participation in farming and annual net income. It also determined variations of socioeconomic status of the vegetable farmers in three years farming, investigate farming practices and evaluate knowledge learned from the services offered by the agricultural institutions as adapted by the local farmers, find out whether there is exchanging experience and networking among stakeholders, investors and farmers ever conducted across geographical boundaries, and confer whether there is significant influence of the farming practice as profession on the socioeconomic of the local famers. Only graduates of agriculture who farmers themselves distributed to eleven municipalities of the province were invited as respondents of the study.

\section{E. Definition of Terms}

To gain common understanding about this study, the authors operationally defined the following terms:

$>$ Socioeconomic of vegetable farmers - this is pertaining to the profile among local vegetable farmers measured across the following indicators such as, age, civil status, family members, household, type of house, ownership, farm size, food security, gender participation in farming and annual net income.

$>$ Tawi-Tawi vegetable growing farms - are the identified farms maned by individual farmer or group of farmers whose concentration was only growing and producing locally grown vegetables for home consumption, marketing and economic purposes.

$>$ Farmers Expenditures - pertains to the totality of expenses incurred by the local farmer(s) while maintaining the operation of their respective farm under cultivation.

Vegetable Farming Practices - referring to the knowledge learned from the agricultural learning institutions adapted by the local farmers in operating their respective farms.

Puhagan's Model of exploring agriculture graduates' socioeconomic in farming

GOAL

PRIORITIES:

Issues and Graduates

(now farmers)

EXPLORE:

Curriculum and

community

CHARACTERISE:

Farming Practices and

Socioeconomic

Profiling
METHOD
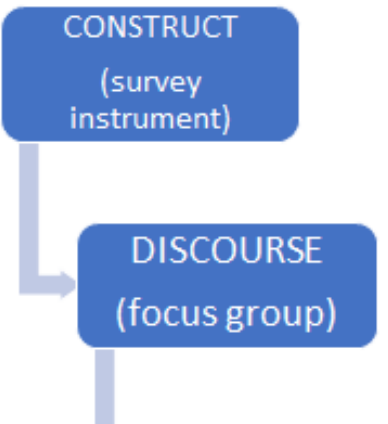

REACH

community survey

Fig 1:- Puhagan's Model
ANALYSIS

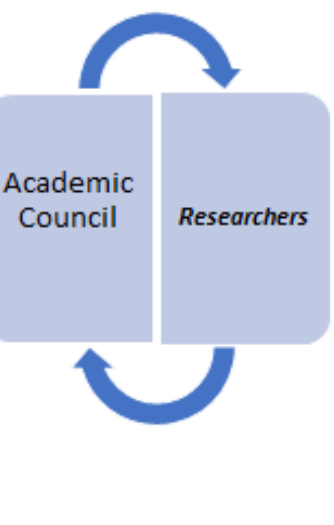




\section{REVIEW OF RELATED LITERATURE}

This study perceives small-scale farming households as the largest group of poor households are below the national poverty line and below the extreme poverty line; in rural areas that may have larger percentage of these extremely poor households have a male head. In TawiTawi, its population is approximately in bigger number who live along coastal rural areas and almost all are depending on fishing while others engaged in agriculture.

Tawi-Tawi is previously part of Sulu province officially separated as new province by virtue of Presidential Decree No. 302 on September 11, 1973 where Bongao is the first seat of its provincial government. It is a province embracing 106 islands and islets found in Sulu Archipelago between Sulu Sea and Celebes Sea with its shoreline length of 152.2 kilometers (94.6 miles) and a maximum elevation of 549 meters $(1,801 \mathrm{ft})$. This province is volcanic origin and irregular in shape with combined area of 1,087.4 square kilometers approximately 55 kilometers (34 miles) long and about 15-23 kilometers wide subdivided into 11 municipalities (Bongao its capital town, Panglima Sugala, Languyan, Tandubas, Sinumul, Sibutu, Sitangkai, Sapa-Sapa, Mapun, South Ubian and Turtle Islands. It lies at the southwestern part of the Philippines bordering Sabah Malaysia and Indonesia. Poverty in TawiTawi could be measured in terms of income of the individual household residing along vicinity of the province. However, according to Pinder, et.al. 2003, Poverty is not just about low income, however. Poverty is multi-dimensional and includes lack of access to many human rights: clean, safe water; access to primary health care; basic shelter; primary education; enough to eat throughout the year. Even when considering these broader dimensions, poverty analysis tends to look only at those physical aspects and constraints that can be measured (e.g. size of landholding, number of meals eaten each day). It rarely pays attention to the complex social relations of poverty, such as the distribution of resources within households, and how gender roles define access to and control over resources. Nor does it always take into account the lack of opportunities for poor people to access social capital, or participate in democratic processes. Most notably, poor people are unlikely to be able to access markets or benefit from a country's economic growth unless there are policies aimed at ensuring equitable distribution of that growth. Further, the rural poor are not a homogenous group, however: locality, gender, age, status within the community, tribal grouping, level of literacy, and many other social characteristics vary amongst the poor. The socioeconomic in farming can be viewed through categorization mechanic like size of land under cultivation, capacity to enter into the market and by market stratification.

Social characteristics of small-scale farmers are broadly determined by the most vulnerable status like often female headed households, or elderly or child headed households, the chronically sick and / or disabled - with less than sufficient to feed themselves throughout the year.
They are usually far distant from main rail and road routes, occupy the least arable land in the community, and have no resources on which to call in event of a 'shock' (e.g. drought, death, sickness). They usually provide seasonal unskilled labor to large farm estates and out growers' holdings. The needs of this group are for free or cheap farming inputs, for example through agricultural input packs (fertilizer and seed), Pinder, et.al. 2003, retrieved 2019. Again, they often rely on obtaining casual work on larger farms and estates. The approach to this group should be one of enabling and supporting them through to a position of food security and viability, eventually capable of producing a small marketable cash crop in addition to meeting their subsistence needs. They are vulnerable to exploitative buyers (e.g. they are unable to store their surplus and are forced to sell it when prices are low, or they are forced to accept a low price from the only trader who passes through the area). They have the potential to participate, or may well be participating already, in exportoutgrower schemes, or they are functioning as commercially viable, independent small-scale farmers selling on to the domestic market instead.

Another way to categorize farming activity is by stratification within farming community like privately owned corporations producing crops for export, large and medium independent farms ownership on which cash crops are grown mainly for export and for the domestic market, small scale farmers who have surplus for sale to local markets, they grow for subsistence and provide seasonal labor to the farm owners. Subsistence farmers who can barely grow enough for the survival of their households and often run out of produce before the next harvest. Farmers that have a small amount to sell in local markets at harvest time due to their lack access to storage facilities which lead them to sell farm products at low prices.

Farmers are the most vulnerable households who will require long-term social protection and support, the poor households that have potential to achieve a poor but sustainable livelihood, regularly marketing a small surplus, with the eventual possibility of joining an outgrower arrangement, these are poor households with potential to become commercially viable small-scale farmers marketing their surplus in the domestic market.

Also according to C. Pinder 2003, the role of agriculture sets out its objectives in relation to agriculture as a means of economic development, and emphasizes the important role that small-scale agriculture has to play in achieving economic growth and poverty reduction, providing the benefits of that growth are distributed towards the poor, and that poor people are able to articulate their demands.

The overall driving force in agriculture is the globally increasing demand for food and fiber. This is primarily caused by a growing world population with a high demand for food production and a wealthier world population with a higher proportion of meat in the diet (Godfray et. al. 2010). Farmers have resources to adapt management however, 
there may be considerable difference in adaptive capacity between cropping systems and farms depending on their specialization (Reidsma et. al. 2007).

\section{METHODOLOGY}

In initial discussions among the authors, it was agreed at least 110 households comprising the study and the focus was only the potential impact of farming on the socioeconomic status of those graduated agricultural curriculum who are now vegetable farmers themselves. The design used in this study was descriptive survey allowing collection and analysis of data from the respondents representing the entire population. The population comprises individuals who learned knowledge of farming from the curriculum offered by the Tawi-Tawi Regional Agricultural College in three academic years as of 20162019. To meet the objectives of the study, the eleven municipalities of the province as a whole is the setting of the study where respondents equally identified and collected to participate. This was done through purposive technique.

\section{$>$ Procedure}

For data collection, a structured questionnaire was formulated and pretested to group of persons who are not the intended respondents of this study in order to gain its reliability and validity prior to the conduct of the study. Respondents were purposely identified in the eleven municipalities respectively. In its first year, there were 110 pieces questionnaire distributed and only 100 pieces returned for statistical analysis. Afterward, this process was done continuously as follow-up in next two years using the same respondents in three years.

\section{Method of analysis}

The data generated were interpreted using percentages and frequencies; mean and standard deviation through Likert scaling of the responses. For more concrete, it used all tools packaged in the SPSS software.

\section{RESULT AND DISCUSSION}

This study is phenomenal in nature across the impact of farming on the socioeconomic of the vegetable farmers and this was conducted in three years where its data interpretation explicitly coupled with the literatures relevant to the issue on Tawi-Tawian Vegetable-Growing Farms: An economic survey in three years farming.

Answer to the problem number 1. What is the socioeconomic status of the local farmers in terms of the following indicators such as, age, civil status, family members, household, type of house, ownership, farm size, food security, gender participation in farming and annual net income?

Table 1 reflects eighty percent of the respondents within 35-40 age bracket, ninety two percent married, sixty percent having 8-10 members in family living in one roof, fifty percent with 2-extended families attached, living in wooden nipa house with personally own garden lot measuring $500-2000 \mathrm{~m}^{2}$ and with food sustained gathered from their respective harvest, almost all male participates in farming and gaining an annual net income of 130k to 160k. Despite of deficiency in stocks, none from the farmers have engage in credit for tehri farm operation and almost if not all of their farms are non-tractor operated. This result reflects further that majority of the Tawi-Tawian vegetablegrowing farms had exclusively outdoor vegetable farming operation in the same system with slight variation in three years.

\begin{tabular}{|c|c|c|}
\hline INDICATORS & PROFILE & PERCENTAGE \\
\hline Age & $35-40$ & $\mathbf{8 0 . 0 0}$ \\
\hline Civil status & Married & $\mathbf{9 2 . 0 0}$ \\
\hline Family members & 6-10 living in one roof & $\mathbf{5 0 . 0 0}$ \\
\hline Household & 2-Extended & $\mathbf{9 6 . 0 0}$ \\
\hline Type of house & Wooden nipa house & $\mathbf{5 3 . 0 0}$ \\
\hline Tenancy Status & Owned lot/farm & $\mathbf{6 4 . 0 0}$ \\
\hline Farm size & Home Garden $\left(500-2000 \mathrm{~m}^{2}\right)$ & $\mathbf{8 0 . 0 0}$ \\
\hline Food security & Sustain & $\mathbf{9 5 . 0 0}$ \\
\hline Gender participation & Male & $\mathbf{6 3 . 0 0}$ \\
\hline Annual Net income & $130 \mathrm{k}-160 \mathrm{k}$ & $\mathbf{9 7 . 0 0}$ \\
\hline Farm Experience before the study & Below 10 years & $\mathbf{1 5 . 0 0}$ \\
\hline Credit for farm operation & None & $\mathbf{9 9 . 0 0}$ \\
\hline Farm Status & Bullock (non-tractor) operated & $\mathbf{1 0 0 . 0 0}$ \\
\hline Number of Farmers/Respondents & $\mathbf{1 0 0}$ & \\
\hline
\end{tabular}

Table 1:- Summary of Socioeconomic profile (Indicators) in three years farming

Answer to problem number 2. Is the variation of socioeconomic profile among vegetable farmers in three years farming?

Here, we briefly reviewed the evidence gathered from the many indicators of socioeconomic to guide us in the discussion. Table 2 reflects the summary of socioeconomic status of vegetable farmers in three years farming. 
ISSN No:-2456-2165

\begin{tabular}{|c|c|c|c|c|c|}
\hline & VARIABLES & $\begin{array}{c}\text { REGRESSION } \\
\text { COEFFICIENT }\end{array}$ & $\begin{array}{c}\text { STD } \\
\text { ERRROR }\end{array}$ & T-VALUE & P-VALUE \\
\hline \multirow{3}{*}{ Socio-economic } & Constant & 1.024 & 0.125 & 3.067 & 0.047 \\
\cline { 2 - 6 } & $2016-2017$ & 5.152 & 2.457 & 2.496 & \\
\cline { 2 - 6 } & $2017-2018$ & 3.458 & 2.150 & 1.452 & 0.169 \\
\cline { 2 - 6 } & $2018-2019$ & 1.876 & 2.921 & \multicolumn{2}{|c|}{ P-value $=\mathbf{2 . 1 3 7 a}$} \\
\hline
\end{tabular}

*=Significant at five percent level

Table 2:- Summary of Socioeconomic in three years farming

The result of Multiple Linear Regression Analysis of the socioeconomic determinants in three years farming reflects the coefficient of determination ( $\mathrm{R}$ square value) of 4.365 , which implies the relationship among the variables of socioeconomic in farming can be explained and taken collectively. However, the observed overall $\mathrm{F}$ value of $3.154 *$ with probably value of 2.137 a greater than the alpha level (P. value > .047) indicates that socioeconomic in farming varies significantly from each other. Therefore, variables such as gender participation in farming, age, civil status, household size, food security and environment, income, family members and farm size are determinants to the socioeconomic of the local farmers in farming. There might have changes in terms of age, civil status and gender participations among vegetable farmers and there was very slight increase in the intensity of family members, and food security and yet trailed variations in three years farming. In the discourse, we considered possibilities of farming improvement with recent evidences about the socioeconomic growth of farmers, particularly the proportion of those working age and gender participation in farming communities. We then discussed the relationship among identified variables more particularly the farming resources which leads to conclusions about the influence of farming in reducing poverty hence, farming improves socioeconomic of those who engaged on it as a vocation. This phenomenon is relative to the FAO reported framework of socioeconomic context in developed countries, a yield-enhancing Green Revolution created considerable employment and greatly improved life for small-scale farmers and landless laborers across the regions. It also brought less expensive and more reliable staple foods to poor consumers. In consequence, crop yields of small-scale farmers and incomes for those in rural employment rose, and poverty and hunger fell dramatically in many countries. (Retrieved 2020).
Answer to the problem number 3. What are farming practices and knowledge learned from the services offered by the agricultural institutions adapted in three years vegetable-growing farms?

The strength of vegetable production pertaining to the area planted with vegetables affecting the socioeconomic depends upon the knowledge learned and practices adapted by farmers in farming. As shown in Table 3, there are collective application of the knowledge learned and adapted by the vegetable farmers where they concentrated much in identifying types and structures of soil in farmland and the suitability of crops to soil and climatic conditions of the place which garnered the highest mean score of 4.51, followed by benefits of crop rotation in maintaining soil health and productivity, and knowledge on mitigating pests and diseases in farm land and the selection of diseaseresistance crops. The totality of the variables resulted to 3.61 mean score which implies adaption of farming practices and learned knowledge in vegetable-growing farms. This phenomenon is identical to the situation reported by Odgaard et al. 2011 that farmers are already adapting to climate change since farming is weather dependent. Such adaptation is self-directing on the part of individual farmer since it requires no external action to do so. However, some Pilipino farming context more particularly in the rural areas, the adaptation of learned knowledge could be fairly effective due to the insufficient farm implements and incapacity of farmers to incorporate new technologies, yet they keep on experimenting new cropping techniques and it only works well when the basic resources for crop growth are sufficient and maintained and the soil and climatic condition cooperates.

\begin{tabular}{|c|c|c|c|}
\hline FARMING PRACTICES AND LEARNED KNOWLEDGE & Mean & Std. & Remark \\
\hline $\begin{array}{l}\text { Approach to uses and management of farming resources and adaptation } \\
\text { to climate change. }\end{array}$ & 2.52 & 0.197 & moderately applied \\
\hline $\begin{array}{l}\text { Intercropping annual, biennial and perennial vegetation to prevent } \\
\text { water tables rising and soil erosion and conserve soil fertility. }\end{array}$ & 2.59 & 0.253 & moderately applied \\
\hline $\begin{array}{l}\text { Knowledge on benefits of ground cover on grazing or cropping } \\
\text { paddocks to maintain or improve soil health (conditions and fertility) }\end{array}$ & 2.65 & 0.302 & moderately applied \\
\hline $\begin{array}{l}\text { 4. Conservation value and personal concept towards diversity of farming } \\
\text { resources }\end{array}$ & 3.03 & 1.021 & moderately applied \\
\hline $\begin{array}{l}\text { Knowledge on mitigating pests and diseases in farm land and the } \\
\text { selection of disease-resistance crops. }\end{array}$ & 3.55 & 1.914 & applied \\
\hline Adapting High-Value crops and market production system, and GMO. & & & \\
\hline
\end{tabular}


ISSN No:-2456-2165

\begin{tabular}{|c|c|c|c|}
\hline & 2.58 & 0.112 & moderately applied \\
\hline $\begin{array}{c}\text { 7. Identification of types and structures of soil in farmland and the } \\
\text { suitability of crops to soil and climatic conditions of the place and the climate } \\
\text { change. }\end{array}$ & 4.51 & 1.025 & strongly applied \\
\hline $8 . \quad \begin{array}{c}\text { Land and soil management: how to interpret results from soil testing } \\
\text { and how to recognize signs of salinity. }\end{array}$ & 1.22 & 1.982 & less applied \\
\hline $9 . \quad \begin{array}{c}\text { Availability and uses native vegetation as sources of farming resources } \\
\text { with high conservation value and the remedy to farm problems in native } \\
\text { vegetation cover in the region over farming period. }\end{array}$ & 4.47 & 0.895 & applied \\
\hline 10. $\quad \begin{array}{c}\text { The benefits of crop rotation in maintaining soil health and } \\
\text { productivity. }\end{array}$ & 4.49 & 0.951 & applied \\
\hline TOTAL & $\mathbf{3 . 6 1}$ & $\mathbf{0 . 6 6 7}$ & applied \\
\hline
\end{tabular}

Table 3:- Farming Practices and Learned Knowledge adapted in vegetable-growing farms

\section{Legend: Verbal Description}

Strongly applied

Applied

Moderately applied

Less

Least applied

\section{Decision value for remark}

$4.50-5.00$

$3.50-4.49$

2.50-3.49

$1.50-2.49$

$0.01-1.47$

Answer to the problem number 4. What is the level of expenditure by farmers in three years vegetable farming?

The increasing percentage of expenditure on vegetables farming related works over time per farm implies slight variation of total area planted to vegetables on individual farms from year to year. This was measured based on the average ratio of area planted to vegetables each year and referred to the mean for all years estimated for each farm surveyed in three years. In fact, the result in table 4 below reflects Land care related expenditure across all vegetable farms such as Land care related works (plowing, harrowing, weeding, lay-out, etc.) that spent highest value in pesos a proportion to the farms that spent money on land care related purposes. This implies that farmers' expenditures across all years, on average, the ratio of expenditures over the area planted each year varied from the mean by only very less percentage. However, a very slight variation annually ranged in the value of peso and the percentage of expenditure could be seen in the table below depending on the year.

\begin{tabular}{|c|c|c|c|c|}
\hline PARTICULAR & ACTIVITIES & $\begin{array}{l}2016- \\
2017\end{array}$ & $\begin{array}{l}2017- \\
2018\end{array}$ & $\begin{array}{l}2018- \\
2019\end{array}$ \\
\hline $\begin{array}{l}\text { A. } \quad \text { Land care related } \\
\text { expenditure across all vegetable }\end{array}$ & & \multicolumn{3}{|c|}{ VALUE IN PESO } \\
\hline & Fencing with wooden posts only & 7,000 & 10,000 & 11,000 \\
\hline & Irrigation if applicable & None & None & None \\
\hline & $\begin{array}{c}\text { Land care related works (plowing, harrowing, weeding, } \\
\text { lay-out, etc.) }\end{array}$ & 10,000 & 10,000 & 12,000 \\
\hline & Management control of pest and weeds & 3,500 & 5,000 & 7,000 \\
\hline & Planting trees and shrubs alongside vegetable garden/farm & None & None & None \\
\hline \multirow[t]{6}{*}{$\begin{array}{l}\text { B. Proportion of farms that } \\
\text { spent money on the following } \\
\text { land care related purposes. }\end{array}$} & & \multicolumn{3}{|c|}{ PERCENTAGE } \\
\hline & Fencing with wooden posts only & 75.00 & 75.00 & 75.00 \\
\hline & Irrigation if applicable & 0.00 & 0.00 & 0.00 \\
\hline & $\begin{array}{l}\text { Land care related works (plowing, harrowing, weeding, } \\
\text { lay-out, etc.) }\end{array}$ & 90.00 & 92.00 & 95.00 \\
\hline & Management control of pest and weeds & 98.00 & 98.00 & 99.00 \\
\hline & Planting trees and shrubs alongside vegetable garden/farm & 0.00 & 0.00 & 0.00 \\
\hline
\end{tabular}

Table 4:- Level of expenditure by farmers on vegetable farming related works

Answer to the null hypothesis stated, "there is no significant influence of vegetable farming practice as profession on the socioeconomic of the local famers."

Table 5 below presents the results of Multiple Linear Regression Analysis and Test for vegetable farming practices where the overall measure as indicated by the Coefficient of determination $\mathbf{R}$ squared value of $\mathbf{8 . 1 2 6}$ implies that the total variation of 
relationship among the variables indicated for vegetable farming practices and socioeconomic of the respondents can be explained and taken collectively. However, the observed overall F value of 8.126 with Probably Value of .006a greater than the alpha level (P. value $>.000$ ) indicates that the significant influence of the vegetable farming practices on the socioeconomic among vegetable farmers in the area if taken collectively is not significant that reject the null hypothesis. Further, this result implies there is significant influence of vegetable farming practices as profession on the socioeconomic of the vegetable farmers in the respective area.

\begin{tabular}{|c|c|c|c|c|}
\hline PREDICTOR VARIABLES & $\begin{array}{c}\text { REGRESSION } \\
\text { COEFFICIENT }\end{array}$ & STD ERRROR & $\begin{array}{c}\text { STUDENTS } \\
\text { T-VALE }\end{array}$ & P-VALUE \\
\hline Constant & 3.001 & 0.326 & 9.1981 & 0.381 \\
\hline Vegetable Farming Practices & 1.468 & 0.092 & 0.4249 & \\
\hline Socioeconomic & 0.140 & 0.626 & 2.8517 & 0.006 \\
\hline \multicolumn{2}{|c|}{ Overall F $=\mathbf{8 . 1 2 6 1}$} & $\mathbf{R}^{2}=\mathbf{0 . 1 4 5}$ & \multicolumn{2}{|c|}{ P - value $=\mathbf{. 0 0 6 a}$} \\
\hline
\end{tabular}

Table 5:- The significant influence of vegetable farming practices as profession on the socioeconomic of vegetable farmers

\section{SUMMARY}

This study based on the issues of local agriculture economic capabilities of the small farmers distributed among municipalities of Tawi-Tawi with its aim of providing feedback with regard to socioeconomic of local vegetable farmers during farm operation periods in three years farming starting 2016 up to 2019. Information resulted from this study is very significant to the farmers and the agriculture service providers like the Tawi-Tawi Regional Agricultural College and other agricultural development line agencies. It collected several indicators of socioeconomic that are deem products of vegetable farming framework and focused on the following specific problems such as: What is the socioeconomic profile among local vegetable farmers in terms of the following indicators such as, age, civil status, family members, household, type of house, ownership, farm size, food security, gender participation in farming and annual net income? Is there variation of socioeconomic status among vegetable farmers in three years farming? What are vegetable farming practices and knowledge learned from the services offered by the agricultural institutions adapted in three years vegetable-growing farms? What is the level expenditure by farmers in three years vegetable farming? Is there significant influence of vegetable farming practice as profession on the socioeconomic of the local famers? Only graduates of agriculture who farmers themselves were invited as respondents. The design used in this study was descriptive and its respondents comprised individuals who learned knowledge of farming from the curriculum offered by the Tawi-Tawi Regional Agricultural College in three academic years as of 2016-2019. For data collection, a structured questionnaire was formulated and the respondents were purposely identified in the eleven municipalities respectively. In its first year, there were 110 pieces questionnaire distributed and only 100 pieces returned for statistical analysis. Afterward, this process was done continuously as follow-up in next two years using the same respondents in three years. The data interpreted using percentages and frequencies; mean and standard deviation through Likert scaling of the responses. For more concrete, it used all tools packaged in the SPSS software. This study is phenomenal in nature across the impact of farming on the socioeconomic of the vegetable farmers in three years where its interpretation explicitly coupled with the literatures relevant to the issue on Tawi-Tawian VegetableGrowing Farms: An economic survey in three years farming. The result reflects eighty percent of the respondents within 35-40 age bracket, ninety two percent married, sixty percent having 8-10 members in family living in one roof, fifty percent with 2-extended families attached, living in wooden nipa house with personally own garden lot measuring $500-2000 \mathrm{~m}^{2}$ and with food sustained gathered from their respective harvest, almost all male participates in farming and gaining an annual net income of $130 \mathrm{k}$ to $160 \mathrm{k}$.

\section{CONCLUSION}

This concludes that Tawi-Tawian vegetable-growing farms had exclusively outdoor vegetable farming operation in the same system with slight variation in three years. Variables such as gender participation in farming, age, civil status, household size, food security and environment, income, family members and farm size are determinants to the socioeconomic of local farmers and the relationship among identified variables leads to conclusions about the influence of farming in reducing poverty hence, farming improves socioeconomic of those who engaged on it as a vocation. It also concludes that the strength of vegetable production pertaining to the area planted with vegetables affecting the socioeconomic depends upon the knowledge learned and practices adapted by farmers in farming. It further concludes that the increasing percentage of expenditure on vegetables farming related works over time per farm implies slight variation of total area planted to vegetables on individual farms from year to year. The farmers' expenditures across all years, on average, the ratio of expenditures over the area planted each year varied by only very less percentage and very slight variation ranged in the value of peso and the percentage of expenditure. Furthermore, it concludes significant influence of vegetable farming practices as profession on the socioeconomic among vegetable farmers in the area respectively. 


\section{RECOMMENDATION}

Based from the result of this study, the authors recommend the following parameters for further study:

$>$ Widen the scope of the study by increasing more indicators of socioeconomic and continue the quest in determining the variation of socioeconomic status among vegetable farmers in more years coming.

> Conduct similar study involving other farms like livestock and poultry raising, pomological farming, floriculture and landscape than just vegetable farming only in determining farming practices and knowledge level of the farmers.

\section{REFERENCES}

[1]. Agri-environmental indicator- commitments, 2015. Retrieved 2019.

[2]. Angel Paniagua, et.al., The Socioeconomics of Agriculture by King's College London. Great Britain. Social and Economic Development - Vol. I - The Socioeconomics of Agriculture. Retrieved 2019.

[3]. Aruni Weragoda, et.al., 2017. Australian vegetablegrowing farms: An economic survey, 2015-16 and 2016-17. Research by the Australian Bureau of Agricultural and Resource Economics and Sciences Research.

[4]. Caroline Pinder, et.al., The socio-economic impact of commercial agriculture on rural poor and other vulnerable groups: A Working Document, Department for International Development - Zambia, February 2003. Retrieved 2019.

[5]. Cary, J., Webb, T. and Barr, N. 2002, Understanding Landholders' Capacity to Change to Sustainable Practices - Insights about Practice Adoption and Social Capacity for Change, Bureau of Rural Sciences, Canberra. Retrieved 2018

[6]. Cramb (ed.), Soil Conservation Technologies for Smallholder Farming Systems in the Philippine Uplands: A Socioeconomic Evaluation, ACIAR Monograph no. 78, Canberra. Retrieved 2019

[7]. Davis, et.al., 2007, 'Strengthening agricultural education and training in Sub-Saharan Africa from an innovation systems perspective: Case studies of Ethiopia and Mozambique' The Journal of Agricultural Education and Extension, vol. 14, no. 1, pp. 35-51.

[8]. Food and Agriculture Organization (FAO). 2007. Agriculture and Consumer Protection Department. Rome, Italy Available from http://www.fao.org/ag/ca/ (Accessed November 2007).

[9]. Gupta, R., Hobbs, P.R., Sayre, Ken. 2007. The role of conservation agriculture in sustainable agriculture. The Royal Society. Pg. 1-13.

[10]. Haberkorn, G., MacGregor, C., Kelson, S. and Charalambou, C. 2001, Compilation of a Database of Socioeconomic Indicators for the Rangelands, Bureau of Rural Sciences, Canberra. Retrieved 2018
[11]. Kirchmann, H., Thorvaldsson, G. 2000. European Journal of Agronomy. Challenging Targets for Future Agriculture. Vol. 12, Issues 3-4. Pg 145-161.

[12]. Mues, C., Roper, H. and Ockerby, J. 1994, Survey of Landcare and Land Management Practices: 1992-93, ABARE Research Report 94.6, Canberra. Retrieved 2018

[13]. Natural Resources and Agricultural Productivity." National Research Council. 2012. A Sustainability Challenge: Food Security for All: Report of Two Workshops. Washington, DC: The National Academies Press. doi: 10.17226/13378.

[14]. Pawley, W.H. 1963. Possibilities of Increasing World Food Production. Food and Agriculture Organization of the United Nations. Rome, Italy. Pg 98.

[15]. Röling, N \& Pretty, JN 1997, 'Extension's role in sustainable agricultural development' in: eds. BE Swanson, RP Bentz \& AJ Sofranko, Improving Agricultural Extension: A reference manual, Food and Agricultural Organisation of the United Nations (FAO), Rome.

[16]. Roser, Max (2013-10-17), "Land Use in Agriculture Our World in Data", Our World in Data, University of Oxford, retrieved February 13, 2017.

[17]. Sulu Archipelago Rain Forest by World Wildlife Fund. 1250 24th Street, N.W., Washington, DC 20037. Retrieved 2019.

[18]. The Chronicle of Love Mindanao: Retrieved, 2019.

[19]. The Organization for Economic Co-operation and Development (OECD) (no date), 'Human Capital' Glossary of Statistical Terms, Available from: $\quad<$ http://stats.oecd.org/ glossary/ detail.asp?ID=1264>, 2015.

[20]. The World Bank 2011, What is Social Capital: 2015.

[21]. Webb, T., Cody, K., Mues, C. and Harrison, B. 2003, Social and Economic Information for NRM: An Initial Discussion Paper, National Land and Water Resources Audit. Retrieved 2018 